Copy № 19

APAE Memo - 321

AEC Research and

Develnpment Report

UC-8I, Reactors-Power

[Special Distribution]

\title{
detailed stress analysis of PM-2A steam generator tube sheet
}

Contract No. AT[30-1]-2639

with U. S. Atomic Energy Commission

New York Operations Office

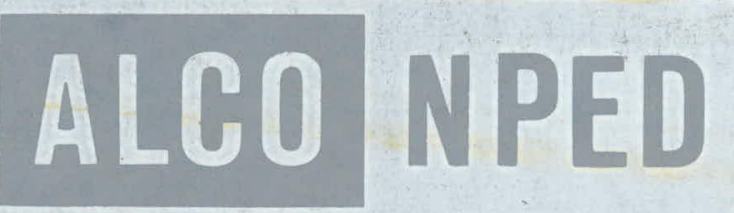

ALCO PRODUCTS, INC. NUCLEAR POWER ENGINEERING DEPARTMENT 


\section{DISCLAIMER}

This report was prepared as an account of work sponsored by an agency of the United States Government. Neither the United States Government nor any agency Thereof, nor any of their employees, makes any warranty, express or implied, or assumes any legal liability or responsibility for the accuracy, completeness, or usefulness of any information, apparatus, product, or process disclosed, or represents that its use would not infringe privately owned rights. Reference herein to any specific commercial product, process, or service by trade name, trademark, manufacturer, or otherwise does not necessarily constitute or imply its endorsement, recommendation, or favoring by the United States Government or any agency thereof. The views and opinions of authors expressed herein do not necessarily state or reflect those of the United States Government or any agency thereof. 


\section{DISCLAIMER}

Portions of this document may be illegible in electronic image products. Images are produced from the best available original document. 
INSTRUCTIONS: This form should accompany each UNCLASSIFIED document the first time it is submitted to the USAEC Office of Technical Information Extension, Post Office Box 62, Oak Ridge, Tennessee.

Document Title Detailed Stress Analysis of PM2A Steam GeneratoDate of Document July 20, 1962 Tube Sheet

Author(s) J. J.Busuttil

Contract No. AT(30-1)-2639

1 Research and Development Report Enclosed is a TID-4500 Standard Distribution Report as defined in AEC Manual Chapter 3202. No Journal Publication or Oral Presentation is Intended. (Use Section II or III below if Journal Publication is Intended or Section IV if Oral Presentation is Intended.)

1. $\square$ Complete TID-4500 distribution has been made, including copies to the Office of Technical Services, Department of Commerce (OTS sale price is $\$$ _ ). The number of copies specified in TID-4500 have been forwarded to the Office of Technical Information Extension for stock and for further distribution to domestic and foreign depository libraries, foreign exchange organizations, etc., and for announcement in Nuclear Science Abstracts.

2. Document has been printed but complete TID-4500 distribution has not been made. Copies are being furnished for the Office of Technical Information Extension to:

a. Make complete TID-4500 distribution including copies to OTS (sale price is \$__) and to depository libraries, etc.

b. Make distribution to OTS and depository libraries, etc. AEC and other Government agency distribution has been made in accordance with TID-4500 (OTS sale price is \$__ ).

c. $x$ Other. Please specify Comply with special distribution requested by AEC-NYOO.

3. $\square$ No copies have been printed for TID-4500 and OTS distribution. OTI may reproduce from copy enclosed and make TID-4500 distribution, including copies to OTS for public sale, depository libraries, etc. Enclosure is:
a. $\square$ Printed copy
b. $\square$ Typed copy
c. $\square$ Reproducible or multilith plates

(Up to 25 copies will be furnished to authors if desired. Indicate number .)

4. $\square$ This document, previously distributed as a classified report, has been declassified with $\square$ without $\square$ deletions. OTI may reproduce from their master copy and make TID-4500 distribution, including copies to OTS for public sale, and to depository libraries, etc.

(Up to 25 copies will be furnished to authors if desired. Indicate number

$.

11. $\square$ Document Enclosed is a TID-4500 Standard Distribution Report which is also intended for Journal Publication:

1. TID-4500 (AEC) distribution has been made. Copies are enclosed for OTI to make single copy distribution to OTS and to the domestic depository libraries, and for announcement in NSA.

2. $\square$ Copies are being furnished OTI to make TID-4500 (AEC) distribution, and single copy distribution to OTS and to the domestic depository librarles, and for announcement in NSA.

3. From the copy enclosed, OTI is requested to reproduce in Microcard form and make TID-4500 (AEC) distribution, domestic depository library distribution and send 1 full size copy to OTS, and announce in NSA.

Document enclosed has or will be submitted for publication in the following scientific journal:

(Name of Journal)

(Expected date of issuance)

111. $\square$ Document enclosed is intended for publication in a journal whose publication policy precludes advance distribution within the AEC and single copy distribution to OTS and to domestic depository libraries.

1. Paper has been or will be submitted for publication in the following scientific journal:

$4 \therefore \quad$ (Name of Journal)

(Expected date of Issuance)

(NOTE:.OTI will hold this document for internal use and will not announce in NSA. No further distribution will be made except in unique circumstances when the report is required by present work of another AEC Contractor in advance of the paper's appearance in the journal. Such further distribution by OTI will be limited to specific requests for this information.) 
IV. $\square$ Document enclosed is intended for Oral Presentation.

Name, Location, Sponsor of Meeting

Date

Publication plans are:

1. $\square$ This paper will be included in the published proceedings of the meeting.

2. $\square$ This paper will not be included in published proceedings. After the date indicated above:

a. $\mathrm{OTI}$ is requested to reproduce and make TID-4500 distribution, including copies to OTS, depository libraries and announce in NSA.

b. $\square$ We (originator) will make TID-4500 distribution, including copies to OTS. (Note: When printed, please transmit copies to OTI with a new PRF appropriately checked in Section I.)

c. $\square$ Paper will be submitted for journal publication. (NOTE: When paper is submitted for journal publication, please submit to OTI a new PRF appropriately checked in either Section II or III.)

V. $\square$ Document enclosed is an internal or informal report not intended for TID-4500 Standard Distribution, Journal Publication or Oral Presentation.

AEC Manual Chapter 3202 requires that informal reports generally be given TID-4500 distribution, and that technical information contained in internal reports also appear in a distributable document which receives appropriate distribution.

Chapter 3202 does recognize that issuing organizations may wish to recommend distribution limitations for informal reports and internal reports (subsequently distributed extemally) under certain conditions. It also provides for negotiation between OTI and the originator, or OTI and the cognizant AEC Program Division if distribution limitations specified by the originator appear questionable to OTI.

Recommendations are:

1. OTI is $\square$ is not $\square$ to make selected positive distribution to certain AEC contractors as appropriate.

2. OTI is $\square$ is not $\square$ to fill requests for this dosument frum ARC contractors.

3. OTI is $\square$ is not $\square$ to selectively distribute and fill requests for this document from other Government agencies.

4. OTI is $\square$ is not $\square$ to make a single copy available to OTS and announce in NSA.

IF DISTRIBUTION LIMITATIONS ARE INDICATED ABOVE, LIST JUSTIFICATION OR REASONS AS REQUIRED BY AEC MANUAL CHAPTER 3202.

Patent clearance for the document cited in this Publication Release form has $[\boldsymbol{X}$ has not $\square$ been obtained. attached.

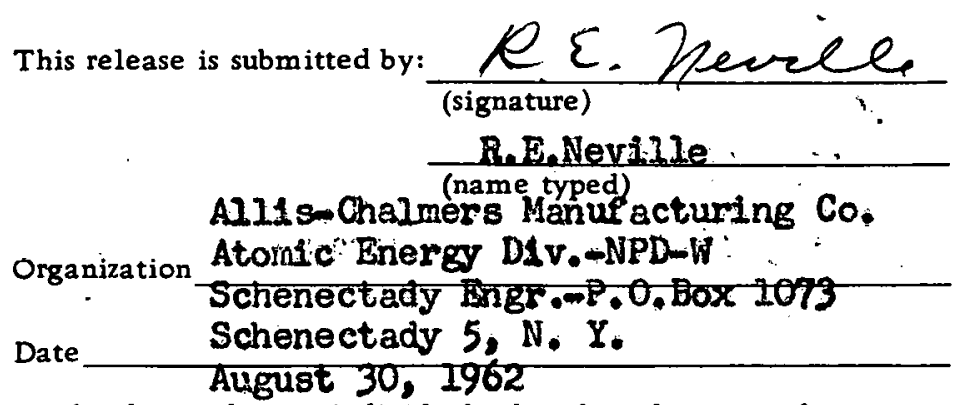

If it is desired that correspondence concerning this document be directed to an individual other than the name above, please indicate 
AEC Research and Development Report UC-81, Reactors, Power (Special Distribution)

DETAILED STRESS ANALYSIS OF

PM-2A STEAM GENERATOR TUBE SHEET

By

J. J。Busuttil

Approved By:

E. W. Schrader, Acting Project Engineer

Issued: July $\cdot 20,1962$

Contract No.AT(30-1)-2639

with U.S. Atomic Energy Commission

New York Operations Office

ALCO PROBUCTS, INCOR PORATED

Nuclear Power Engineering Department

Post Office Box 414

Schenectady 1, N. Y. 


\section{AEC LEGAL NOTICE}

This report was prepared as an account of Government sponsored work. Neither the United States, nor the Commission, nor any person acting on behalf of the Commission:

A. Makes any warranty or representation, expressed or implied, with respect to the accuracy, completeness, or usefulness of the information contained in this report, or that the use of any information, apparatus, method, or process disclosed in this report may not infringe privately owned rights:

B. Assumes any liabilities with respect to the use of, or for damages resulting from the use of any information, apparatus, method, or process disclosed in this report.

As used in the above, "person acting on behalf of the Commission" includes any employee or contractor of the Commission, or employee of such contractor, to the extent that such employee or contractor of the Com= mission, or employee of such contractor prepares, disseminates, or pro= vides access to, any information pursuant to his employment or contract with the Commission, or his employment with such contractor.

\section{ALCO LEGAL NQTICE}

This report was prepared by Alco Products, Incerporated in the course of work under, or in connection with, eontract NQ: AT $(30=1)=2639$, issued by U.S. Atomic Energy Commission, NYQQ; and subject only to the rights of the United States, under the provisions of this contract, Alce products, Incorporated makes no warranty of representation, express of implied, and shall have no liability with respect to this report or any of its contents or with respect to the use thereof or with respect to whether any such use will infringe the rights of others. 


\author{
External \\ Copies \\ 1-2 : New York Operations Office \\ U. S. Atomic Energy Commission \\ 376 Hudson Street \\ New York 14; New York \\ Attn: I. M. Adler \\ 3 \\ New York Operations Office \\ U. S. Atomic Energy Commission. \\ 376 Hudson Street \\ New York 14, New York: \\ Attn: Library \\ 4-6 U. S Atomic Energy Commission \\ Washington 25, D. C. \\ Attn: Chief, Water Systems Project \\ Branch (Army Reactors) \\ Division of Reactor Development \\ Mail Station F-311 \\ 7 \\ U. S. Atomic Energy Commission \\ Washington 25, D.C. \\ Attn: Chief, Evaluation and \\ Planning Branch \\ Civilian Reactors \\ Division of Reactor Development \\ Mail Station F-311 \\ U. S. Atomic Energy Commission \\ Chief, New York Patent Group \\ Brookhaven National Laboratory \\ Upton, New York \\ Attn: Harman Potter
}


Idaho Nuclear Power Field Office

U. S. Army Engineer Reactors Group

P. O. Box 2108

Idaho Falls, Idaho

10

U. S. Atomic Energy Commission

Reports and Statistics Branch

Division of Reactor Development

Washington 25, D。C.

11-12 Office of the Chief of Engineers

Department of the Army

Building $T-7$

Washington 25, D。C.

Attn: Chief, Projects Branch

Nuclear Power Division

13-15 Nuclear Power Field Office

U. S. Army Engineer Reactors Group

: Fort Belvoir, Virginia

Attn: Chief, Nuclear Power

Field Office

16 Nuclear Power Field Office

U. S. Army Engineer Reactors Group

Fort Belvoir, Virginia

Attn: O. I. C. SM-1

17

Chief, U. S. Army Reactors Group

Fort Greely, Alaska

APO 733

Seattle, Washington

$\because$ Attn: O: I. C. SM-1A

- Commanding Officer U. S. Army Polar Research and Development Center

Fort Belvoir, Virginia

Attn: Nuclear Power Officer 


\author{
External \\ Copies \\ DISTRIBUTION (CONT'D) \\ 19-21 Office of Technical Information Extension \\ P. O. Box 62 \\ Oak Ridge, Tennessee \\ $22 \quad$ Union Carbide Nuclear Corporation \\ Oak Ridge National Laboratory \\ Y-12 Building 9704-1 \\ P. O. Box "Y" \\ Oak Ridge, Tennessee \\ Attn: L. D. Schaffer \\ 23 The Martin Company \\ P. O. Box 5042 \\ Middle River, Maryland \\ Attn: AEC Contract Document Custodian \\ 24-25 Combustion Engineering, Incorporated \\ Nuclear Division \\ Prospect Hill Road \\ Windsor, Connecticut \\ Attn: Mr. J. B. Anderson \\ 26 \\ Alco Products, Inc. \\ Post Office Box 145 \\ Fort Belvoir, Virginia \\ Attn: W. C. Best
}

Internal

Copies

$\begin{array}{llrl}27 & \text { K. Kasschau } & 34 & \text { E. W. Schrader } \\ 28 & \text { R. Bell } & 35 & \text { J. J. Busuttil } \\ 29 & \text { C. Klotz } & 36 & \text { D. W. McLaughlin } \\ 30 & \text { J. F. Haines } & 37 & \text { P. E. Bobe } \\ 31 & \text { J. P. Tully } & 38 & \text { F. G. Moote } \\ 32 & \text { E. C. Edgar } & 39 & \text { R. E. Neville } \\ 33 & \text { W. T. Williams } & 40-45 & \text { NPED File }\end{array}$




\section{THIS PAGE}

WAS INTENTIONALLY

LEFT BLANK 


\begin{abstract}
A detailed analysis of the P.M-2A steam generator tube sheet revealed that it is safe from strain cycling damage. The pressure stresses, however, indicate that permanent deformation would take place in the tube sheet at hydrostatic test pressure of 1.5 times design pressure.
\end{abstract}




\section{THIS PAGE}

WAS INTENTIONALLY

LEFT BLANK 
$\underline{\text { Page }}$

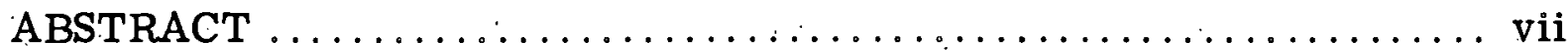

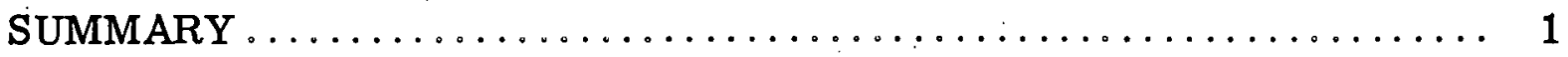

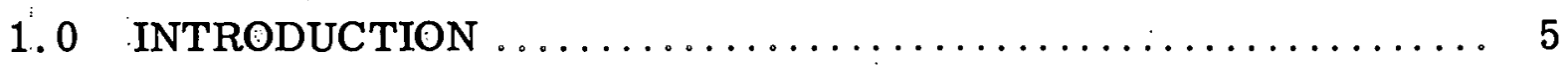

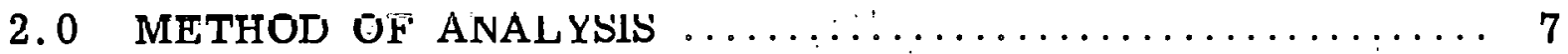

3.0 STRESS AND FATIGUE ANALYSIS $\ldots \ldots \ldots \ldots \ldots \ldots \ldots \ldots$

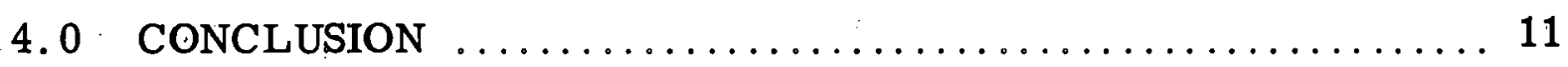

5.0 REFERENCES ................................ 13

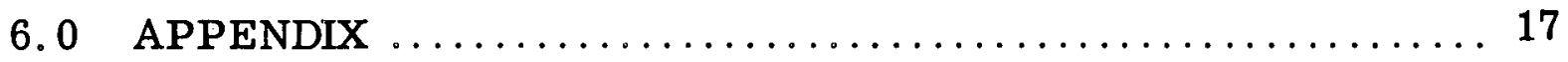

\section{LIST OF ILLUSTRATIONS}

Figure

Title

$\underline{\text { Page }}$

1

Fatigue Diagram PM-2A Steam Generator

Tube Sheet

2 Stress Analysis Schematic PM-2A Tube

Sheet

Biagram of PM-2A Tube Sheet

4 Drawing D-42-205-1-3

35 - inch Tube Layout and Support Plate Study 


\section{THIS PAGE \\ WAS INTENTIONALLY \\ LEFT BLANK}


SUMMARY

The detailed analysis of the PM-2A Steam Generator tube sheet revealed it to be safe from strain cycling damage (Fig. 1). The major cyclic conditions considered were:
a. Startup and shutdown cycle
b. Loss of load cycle
c. Primary hydrostatic test cycle

During operations in the above three categories, the pressure limits established in a paper "Design of Perforated Plates", by $\mathbf{O}^{9}$ Donnell and Langer, are exceeded (Fig。2). This would indicate that permanent deformation would take place in the tube sheet. In the worst case, however, hydrostatic testing of the primary system is expected to occur only five to ten times during lifetime of the plant.

It should also be noted that the original design procedures were those normally used for equipment of this type as defined in TEMA standards. The more sophisticated analysis presented here is based on elastic theory and does not take into account the re-distribution of stress which takes place after initial yielding has occurred. Since the initial yielding (which probably took place during the first hydro-static test) resulted in no leaks or other difficulty and no hazard exists from the fatigue standpoint, continued safe operation can be expected as in the case of other similar vessels designed to the TEMA standards as was the PM-2A steam generator

Table 1 gives at summary of stresses on the PM-2A steam generator tube sheet. 
TABLE 1

\section{SUMMARY STRESS ANALYSIS}

\begin{tabular}{|c|c|c|c|c|c|}
\hline & & $\begin{array}{l}\text { FULL LOAD } \\
\text { TO NO LOAD }\end{array}$ & $\begin{array}{l}\text { STARTUP } \\
\text { CYCLE }\end{array}$ & LIMITS & $\begin{array}{c}\text { HYDRO } \\
\text { PRIMARY }\end{array}$ \\
\hline LOAD & $\begin{array}{c}\text { STRESS INTENSITY } \\
\text { (TYPE AND LOCATION) } \\
\end{array}$ & $\begin{array}{c}\text { STRESS } \\
\text { INTENSITY }\end{array}$ & $\begin{array}{c}\text { STRESS } \\
\text { INTENSITY } \\
\end{array}$ & & $\begin{array}{c}\text { STRESS } \\
\text { INTENSITY } \\
\end{array}$ \\
\hline \multirow{2}{*}{ PRESSURE } & $\begin{array}{l}\text { Average Across Ligament } \\
\text { at Either Surface } \\
\text { at Edge } \\
\text { (Eq. 8A) }\end{array}$ & $\begin{array}{l}X 24,700 \\
Y 33,400\end{array}$ & $\begin{array}{l}X 27,900 \\
Y 40,100\end{array}$ & $\begin{array}{l}28,200 \\
35,600\end{array}$ & $\begin{array}{r}\times 69,000 \\
93,200\end{array}$ \\
\hline & $\begin{array}{l}\text { Average Across Ligament } \\
\text { and Through Thickness } \\
\text { (Eq. 9) }\end{array}$ & & & $\begin{array}{l}18,750 \\
23,700\end{array}$ & \\
\hline $\begin{array}{l}\text { COMBINED PRESS } \\
\text { AND THERMAL }\end{array}$ & $\begin{array}{l}\text { Average Across Ligament } \\
\text { at Either Surface } \\
\text { (Eq. } 8 \& 12 \text { ) }\end{array}$ & $\begin{array}{l}X 39,300 \\
Y 48,000 \\
\end{array}$ & $\begin{array}{l}X 44,300 \\
Y 54,700 \\
\end{array}$ & $\begin{array}{l}56,300 \\
71,000 \\
\end{array}$ & $\mathrm{Y} \mathrm{93,200}$ \\
\hline \multirow{2}{*}{$\begin{array}{l}\text { COMBINED PRESS } \\
\text { AND THERMAL }\end{array}$} & $\begin{array}{l}\text { Peak in Ligaments } \\
\text { (Eq. 10) }\end{array}$ & $\begin{array}{l}\mathrm{X} 46,070 \\
\mathrm{Y} 65,000 \\
\end{array}$ & $\begin{array}{l}X 55,185 \\
Y 78,385 \\
\end{array}$ & & $\begin{array}{l}\mathrm{X} 128,000 \\
\mathrm{Y} 182,000 \\
\end{array}$ \\
\hline & $\begin{array}{l}\text { Peak at Perforations Adjacent } \\
\text { to Rim } \\
\text { (Eq. 11) }\end{array}$ & 17,470 & 20,965 & & 48,800 \\
\hline $\begin{array}{l}\text { CYCLIC THERMAL } \\
\text { SKIN EFFECT }\end{array}$ & $\begin{array}{l}\text { Peak at Surface } \\
\text { (Eq. 12) }\end{array}$ & 14,600 . & 14,600 & & \\
\hline \multirow{2}{*}{$\begin{array}{l}\text { CYCLIC THERMAL } \\
\text { (Temperature Across } \\
\text { Diametral Lane) }\end{array}$} & $\begin{array}{l}\text { Peak in Ligaments } \\
\text { (Eq. 13) }\end{array}$ & & $\begin{array}{l}X 14,650 \\
Y 13,250\end{array}$ & & \\
\hline & $\begin{array}{l}\text { Peak at Holes Adjacent to } \\
\text { Diametral Lane } \\
\text { (Eq. 14) }\end{array}$ & & $X 17,450$ & & \\
\hline
\end{tabular}


+ Hydro (a) 91,000

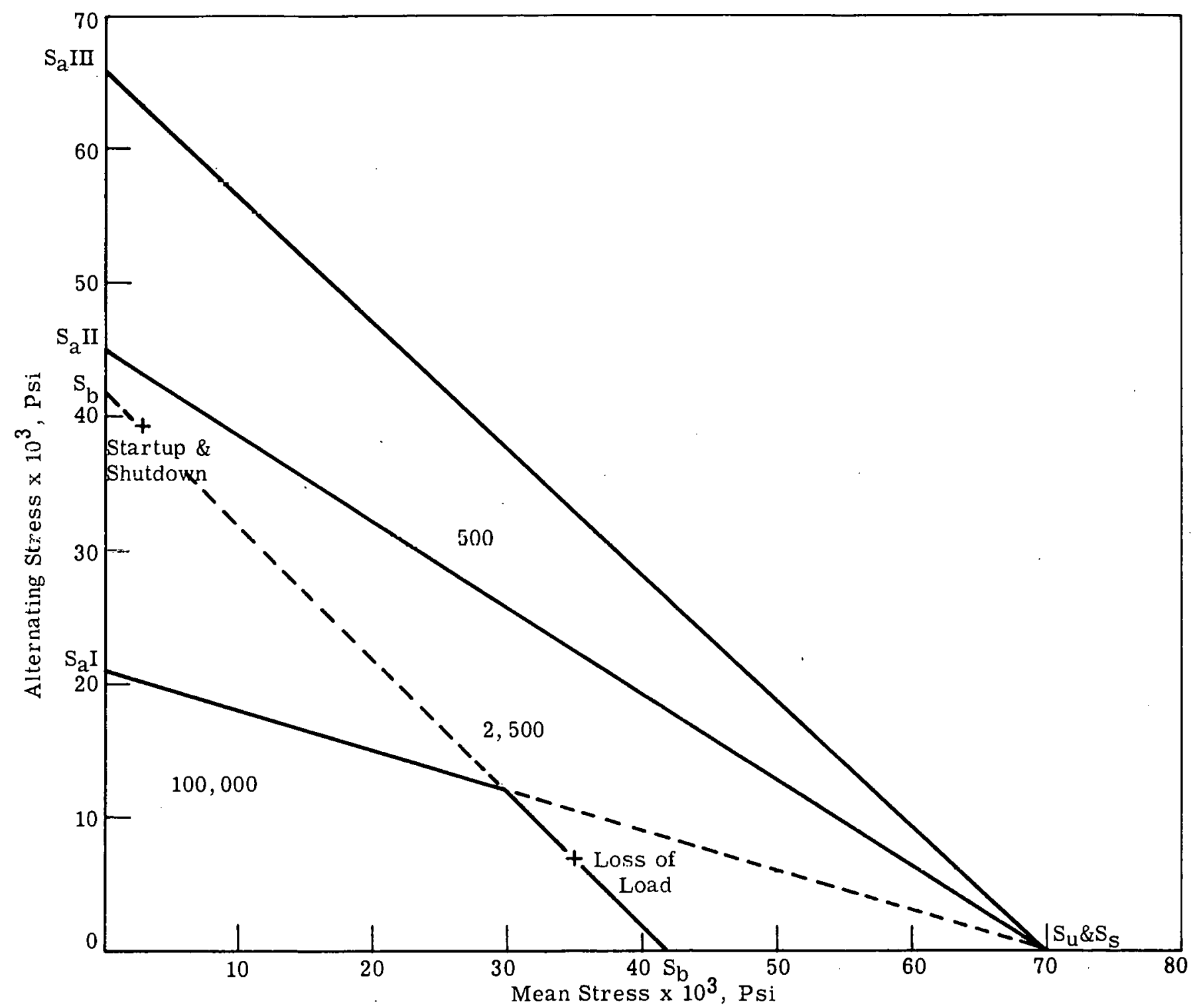

Figure 1. Fatigue Diagram PM-2A Steam Generator Tube Sheet 
THIS PAGE

\section{WAS INTENTIONALLY \\ LEFT BLANK}




\subsection{INTRODUCTION}

This report presents a detailed stress analysis of the PM-2A Steam Generator tube sheet. The Decay Heat Loop Modification Tests; (Contract DA-44-192 ENG-17)* indicated that during decay heat removal, after loss of primary coolant pump and scramming of the reactor, the tube sheet could experience a $\Delta \mathrm{T}$ of approximately $100^{\circ} \mathrm{F}$ across the diametral lane. The temperature difference imposed an additional stress that did not exist with the decay heat removal circuit as originally designed.

At the time of the tests mentioned above, October 1961, a preliminary stress analysis was performed treating the rectangular pattern of holes in the same manner as a square pattern of holes. (Refer to APAE Memo-283 "Preliminary Stress and Fatigue Analysis of the SM-1 Primary System".) The method used(1), which approximates a square pattern, indicated that the sum of the stresses, including those occurring during decay heat removal, were quite high; and a recommendation for a further, ${ }$, more detailed, stress analysis was proposed.

Very little work had been done up to that time on analysis of perforated plates with a rectangular array of holes. In April 1961, however, Grumman Aircraft Engineering Corporation prepared a paper (2) for the subcommittee on stresses in ligaments, of the Pressure Vessel Research Council. This paper was based on the analysis of a perforated circular plate containing a rectangular array. It provided a method to determine the maximum moment and the stresses located at the center and at the edge of the tube sheet. For the stresses in the areas of special interest, a recent paper by $O^{\prime}$ Donnell and Langer $(3)$ provided methods for solution. These stress areas are: peak in ligaments, peak at perforations adjacent to the rim, and peak at holes adjacent to the diametral lane.

* with U. S. Army Engineer Research and Development Laboratories, Fort Belvoir, Virginia 
THIS PAGE

WAS INTENTIONALLY

LEFT BLANK 
The analysis for a perforated circular plate containing a rectangular array of holes, by Grumman Aircraft Research Department as mentioned previously $y_{y}$ was used for this study. : Using this method of analysis, an exact solution for the rectangular pattern of holes with a clamped edge support is possible. The PM-2A tube sheet was assumed to be clamped edge (previous analysis of the $S M-1$ tube sheet $(4)$ had showed it to be clamped edge support) and the moments were determined at $r=0$ and $r=a_{0}$. Since the moments changed in sign from + to - , the tube sheet is not a simply supported plate. With the aid of Fig. 2, it was determined that the tube sheet stress level is within $2 \%$ of that of a true clamped edge. The maximum moments were calculated from the Grumman paper; and, considering the $\mathrm{X}$ and $\mathrm{Y}$ direction separately, the $\mathrm{O}^{\prime}$ Donnell paper was used to evaluate the stresses at various locations caused by pressure and/or thermal effects. The equations and graphs in the $O^{\circ}$ Donnell paper associated with the stress concentrations at the various locations on the plate are based on geometry (a relationship involving the following: ligament thickness, diametral lane width, hole diameter, and diameter of outside ring of holes). Since the PM-2A tube sheet consists of a rectangular pattern, the formulas and graphs were used considering both the $\mathrm{X}$. and $\mathrm{Y}$ direction separately. (Ligament thickness in a rectangular pattern is different in $\mathrm{X}$ and $\mathrm{Y}$ direction.) This fact makes possible the evaluation of the stresses at various locations on the tube sheet. 


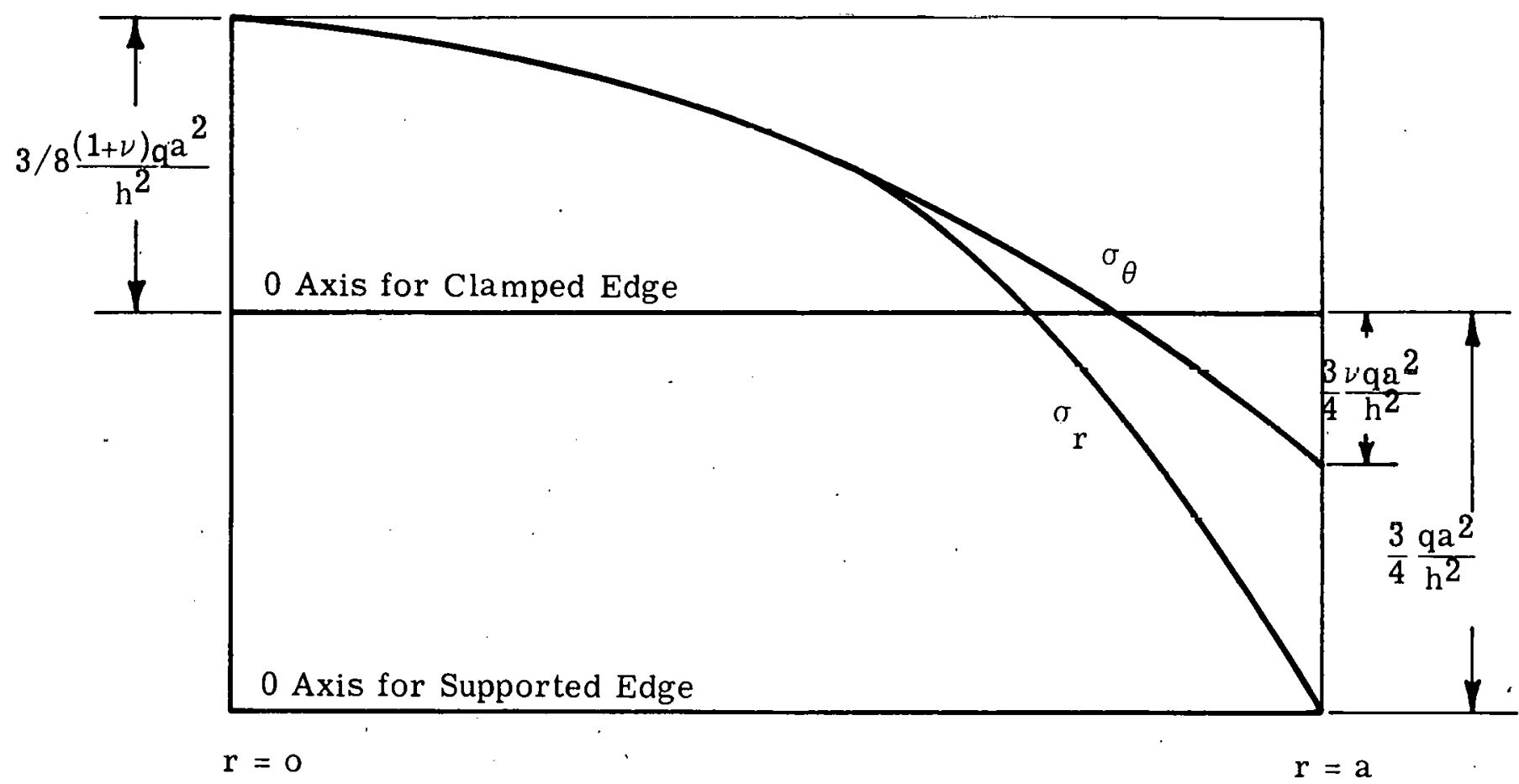

where: $\nu=$ Poisson's Ratio

$$
\begin{aligned}
& \mathrm{q}=\Delta \mathrm{P} \text { (Primary Pressure - Secondary Pressure) } \\
& \mathrm{h}-\text { Tubc Shcct Thickness } \\
& \mathrm{a}=\text { Plate Radius } \\
& \sigma=\text { Stress Intensity } \\
& \theta=\text { Edge Rotation } \\
& \dot{\mathrm{r}}=\text { Radial Coordinate }
\end{aligned}
$$

Figure 2. Stress Analysis Schematic of Tube Sheet, PM-2A

(From "Theory of Shells and Plates" Timoskenko, Page 61) 


\subsection{STRESS AND FATIGUE ANALYSIS}

The three major stress conditions considered in this analysis are based on the results of the SM-1 analysis that showed them to be of maximum severity. They are as follows:

1. Normal startup and shutdown cycles (including scrams that result in a plant cooldown).

2. The full load to no load cycle (loss of load).

3. Hydrostatic testing of the primary side.

The stresses in both the $\mathrm{X}$ and $\mathrm{Y}$ direction are evaluated and, as suspected, the stresses in the $\mathrm{Y}$ direction are more severe, primarily because the ligament thickness in the $\mathrm{Y}$ direction is less than that in the $\mathrm{X}$ direction:

The primary hydrostatic test imposes the maximum stress in the $\mathrm{Y}$ direction, as a result of pressure alone. This stress is the average across the ligament at either surface, and its stress value is 93,200 psi in contract to the limit of stress value given in O'Donnell's paper; that is, $35,200 \mathrm{psi}(5 / 8 \times 1.5$ yield strength). This limit is specified in order to prevent excessive deflection and permanent deformation in the tube sheet. The excessive deflection and permanent deformation in the tube sheet does not, however, result in so severe a condition in the $U$ tube arrangement (PM-2A) as in the straight tube design. In the U tube design, the deflection can be absorbed by the tubes which are not held so rigidly as the fixed-head type. Hydrostatic tests are performed initially on the Steam Generator at 1.5 times the design pressure in order to meet code requirements. . During this test, the primary side is at 3000 psig; and the secondary side, at 0 psig. In addition, when the steam generator is installed in the primary loop, it again is given a hydrostatic test at approximately design pressure on the primary side. To date, it is estimated that the steam generator has undergone five hydrostatic tests with no leakages resulting at the tube sheet. It is recommended, however, that in future, primary, hydrostatic tests, the primary system be brought up to design pressure rather than 1.5 design. This will lower the differential pressure across the tube sheet to 2000 psig and reduce the stress (Y direction) to 62,000 psi.

The startup cycle and the loss-of-load cycle exceed the O'Donnell specified pressure limits by 42.5 percent and 18.5 percent respectively, based on the average stress across the ligament in the Y direction.: This tube sheet was designed and manufactured with a rectangular pattern of 
holes; and the ligament thickness changes depend on the radial from the center chosen. It has been shown by I. Malkin $(5)$ that there is less impairment of the resistance of a plate to bending if it is uniformly perforated with holes of a given diameter on a triangular layout than a square layout. This fact indicates that a triangular pattern of holes can provide greater ligament thickness for the same number of holes than a square (or rectangular) array of holes can provide. In future designs, the limit criteria can be met by providing a greater ligament thickness, by either a triangular pattern of holes or by a larger tube sheet surface area that utilizes a rectangular pattern of holes. 


\section{0 CONCLUSION}

The fatigue analysis shows that there is no danger of failure from this standpoint, as summarized below. (See Fig. 1.)

1. Startup cycles are estimated at 900 and the analysis show the capability of 2,500 cycles.

2. Loss of load cycles above 50 percent are estimated at 15,000 and the analysis shows 100,000 allowable.

The calculated hydro-test stress is very high and may have caused permanent deformation in the tube sheet. From the fatigue standpoint, however, it is not excessive because it will occur only five to ten times during the plant lifetime.

In future designs, in order to meet the limiting criteria, a greater ligament thickness must be provided, either by a triangular pattern of holes or by a larger tube sheet surface area utilizing a rectangular pattern of holes.

In this connection, it should be pointed out that future hydro-static testing of the primary system as a whole may be limited by radiation damage criteria in the reactor vessel, and nothing in this report should be considered as superseding such limitations. 
THIS PAGE

\section{WAS INTENTIONALLY \\ LEFT BLANK}




\subsection{REFERENCES}

1. Gardner, $K_{\circ} \cdot A_{\circ}$,"Heat Exchanger Tube Sheet Design - 2"; "Journal of Applied Mechanics", June 1952

2. Grumman Aircraft Engineering Corporation Research Report RE - 145, April 1961, "Analysis of a Perforated Circular Plate Containing a Rectangular Array of Holes".

3. O'Donnell, W. J., and Langer, F。. B., "Design of Perforated Plates", ASME Paper 61-WA 115, January 1962.

4. Busuttil, $J_{\circ}: J_{0}$, Chittum, R. A., "Detailed Stress Analysis of the SM-1 Steam Generator Tube Sheet", APAE Memo-319, July, 1962 .

5. Malkin, $I_{0}$, "Notes on a Theoretical Basis for Design of Tube Sheets of Triangular Layout", Transactions of the ASME, April 1952. 


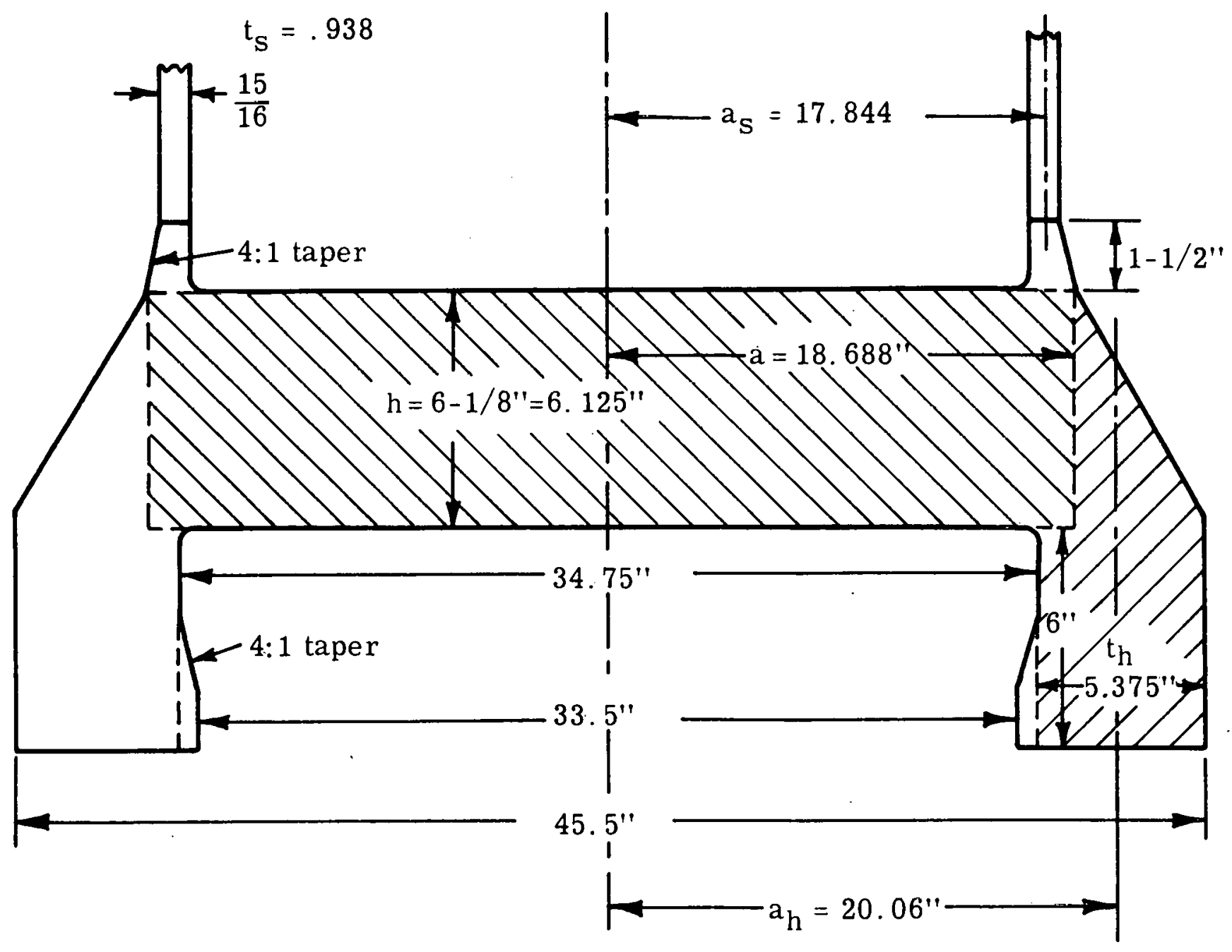

Figure 3. Tube Sheet Stress Analysis 


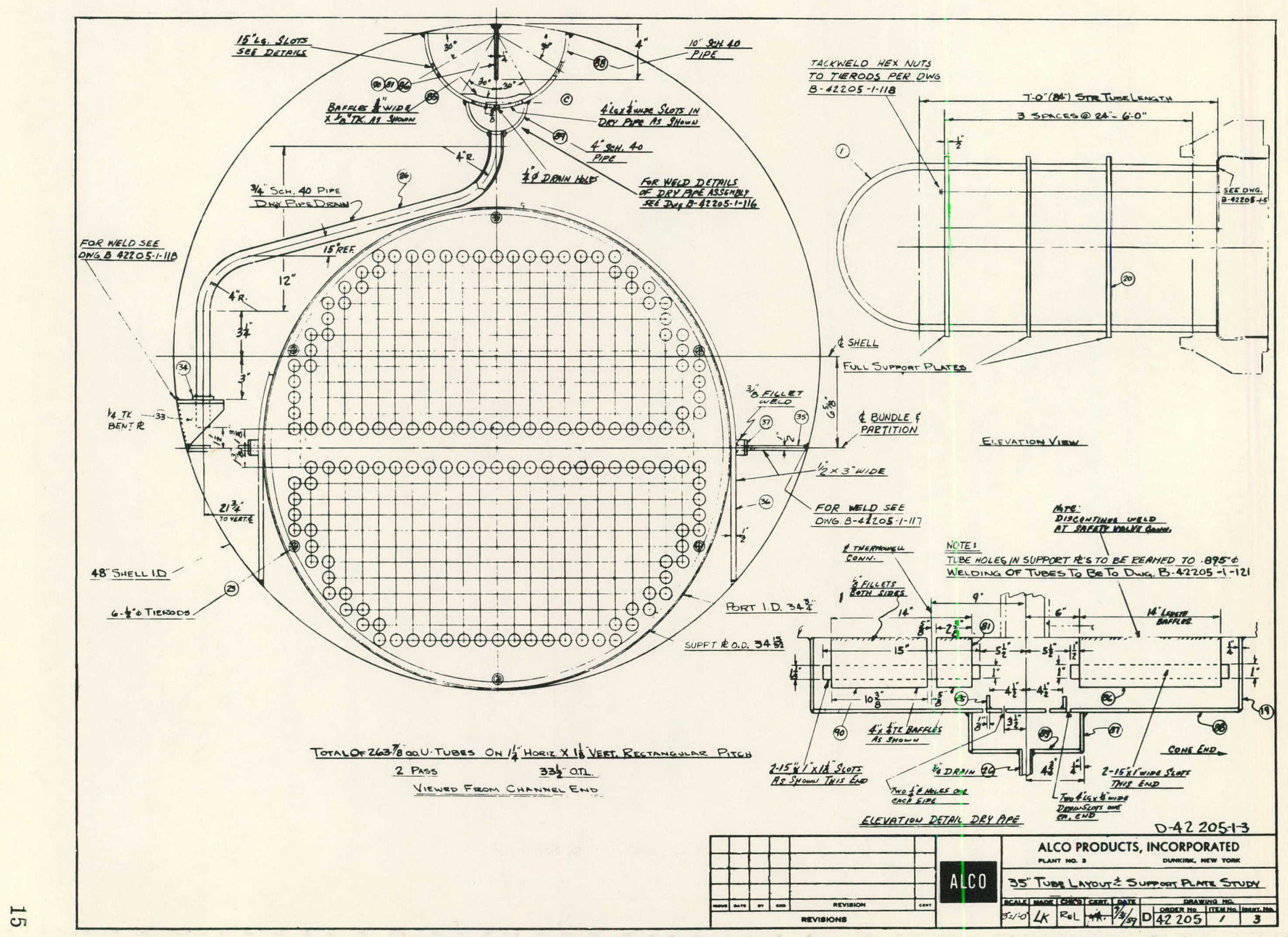




\section{0 APPENDIX}

The calculations that follow on Sheets 1-17 were performed in support of the PM-2A Steam Generator Tube Sheet Stress analysis. 
ALCO PRODUCTS INC.

CHKD. BY

SUBJECT

SHEET NO. 2

(5) $\quad K_{i}=1 / 3\left[1-0.630 \frac{2 F_{E}}{t}\right]=\frac{1}{3}\left[1-0.630\left(\frac{.0515}{6.125}\right)\right]=\frac{1}{3}(.9676)=.3225$

(6) $K_{2}=1 / 3\left[1-0.630 \frac{2 F_{h}}{t}\right]=\frac{1}{3}\left[1-0.650\left(\frac{.435}{6.125}\right)\right]=\frac{1}{3}(.9553)=.3184$

(I) $C_{1}=K_{1}(2 \bar{H} \xi)^{3} t=3225(.315)^{3} 6.125=06170$

(d) $C_{2}=K_{2}\left(2 \bar{H}_{\lambda}\right)^{3} \tau=.3184(.435)^{3} b .125=.1600$

(13)

$$
\begin{aligned}
\cos 2 E=\frac{-D_{1}-D_{2}}{D_{1}-2 D_{2}+D_{3}-2 D_{4}}=\frac{E}{E}\left[\frac{7.87-6.93}{7.87-398+6.83-9.28}\right] \\
=\frac{-1.04}{1.44}=.725 \quad \therefore 2 Z=43.5 \\
\therefore R=21.8^{\circ}
\end{aligned}
$$

(14) $D^{\prime}=1 / 8[3(7.87)+2(1.99)+2 \quad 1.3(6.83)] E=\frac{1}{9}(57.26)=7.157 \mathrm{E}$

$$
\begin{aligned}
& D_{1}=7.87 \\
& D_{2}=1.99 \\
& E D_{3}=6.33
\end{aligned}
$$$$
\frac{D_{4}}{E}=4.64
$$

is 
BY

DATE

CHKD. BY

DATE

SUBJECT

SHEET NO..3.

JOB NO.

Or tho tropic plate - effective stiffness conf.

(9)

$$
\begin{aligned}
D_{1} & =\frac{E t^{3}}{12 \xi \lambda}\left[\frac{\xi(2 \bar{H} \lambda)}{\left(1-V^{2}\right)}+\frac{2}{\xi}(2 \bar{H} \xi)^{2}\right] \\
& =\frac{E(6.125)^{3}}{12(1.125)(1.25)}\left[\frac{1.125}{.91}(.435)+\frac{.438}{1.125}(.315)^{2}\right] \\
& =E(13.65)[.538+.0386]=7.87 E^{\prime}
\end{aligned}
$$

(10)

$$
\begin{aligned}
D_{2} & =\frac{\gamma E T^{3}}{29 \xi \lambda}\left[\frac{\xi\left(2 \bar{H}_{\lambda}\right)+\lambda\left(2 \bar{H}_{\xi}\right)}{\left(1-V^{2}\right)}\right] \\
& =\frac{(.3) E(230)}{24(1.125)(1.25)}\left[\frac{1.125(.435)}{-91} \pm . .25(.315)\right] \\
& =2.05 E\left[\frac{.499+.394}{.91}\right]=2.05(.92) E=1.99 E
\end{aligned}
$$

(ii)

$$
\begin{aligned}
& D_{3}=\frac{E t^{3}}{12 \frac{\partial}{3} \lambda}\left[\frac{\lambda\left(2 \bar{H}_{\xi}\right)}{\left(1-v^{2}\right)}+\frac{d}{\lambda}(2 \bar{H} \lambda)^{2}\right] \\
& =\frac{E(230)}{12(1.125)(1.25)}\left[\frac{1.25(.315)}{.91}-\frac{4 z}{1 .}-(.435)^{2}\right]
\end{aligned}
$$

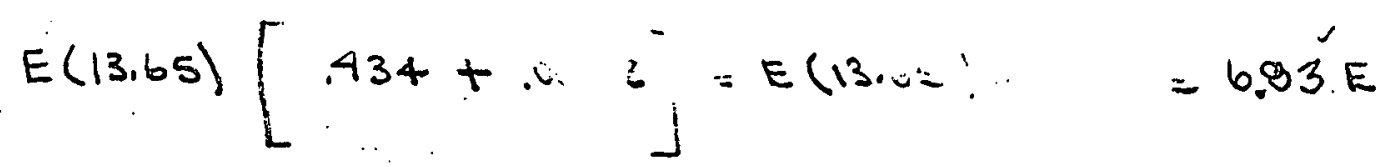

(12)

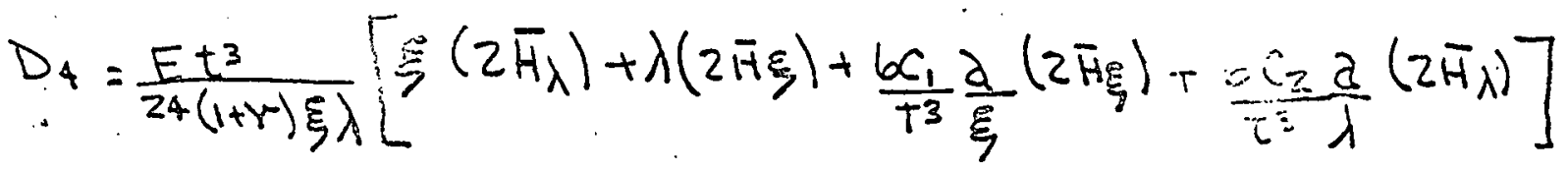

$$
\begin{aligned}
& =\frac{E(230)}{24(1.3)(1.125)(1.25)}\left[(1.125)(1435)+1.25(.315)+\frac{6(.0617)(.438)(315)}{230(1.125)}+\frac{6(16)(.438)(.4 .35)}{230(1.25)}\right] \\
& =E(525)(.8948)=E(4,64)
\end{aligned}
$$

$\nu^{2}$ 
BY

DATE

CHKD. घY

DATE.

SUBJECT

SHEET NO.A

JOB NO.

$\cos 4 B=\cos 273^{\circ}$

(15)

$$
\begin{aligned}
& \frac{M_{\alpha}}{r_{0}^{2}}=\frac{q}{32 D^{2}}\left[\left(\left(D_{1}+2 D_{2}+D_{3}\right)+\left(D_{1}-D_{3}\right) \cos 2 B\right)\left(\frac{\left(0^{2}-r^{2}\right.}{\cot _{0} t}\right)\right. \\
& -\frac{r^{2}}{C_{0}}\left[\frac{3 D_{1}}{2}+D_{2}+3 D_{3}+D_{4}+2\left(D_{1}-D_{3}\right) \cos 2\right. \\
& +\frac{1}{2}\left(D_{1}-2 D_{1}+D_{3}-2 D_{4}\right) \cos 4 D_{2} \\
& =\frac{8}{320}\left[\left[\begin{array}{c}
7.87+3.98 \\
4
\end{array}\right.\right. \\
& \begin{array}{r}
-r^{2}\left[(11.8+1.99+10.25+3.0 .67)+2\left(7.9790^{28}-6.83\right)(-725)+.5(7.87+3.98+6.83-9.28)\right. \\
\times(.0533)
\end{array} \\
& =\frac{q E}{32 \frac{1}{E}}\left[17.93 \cdot r_{0}^{2}-45.14 r^{2}\right] \\
& 1295(4.36)(17.93)(350) \times 10^{-3}=35,100
\end{aligned}
$$

$d @ r=r_{0}$ Edae

$$
12 \varepsilon \quad \ldots .06 .00^{-3}\left[-27.21 r_{0}^{2}\right]=-53 .=00
$$

For Clomped edqe Fiquz

$$
\frac{3 / 4\left(\frac{g^{\prime} a^{2}}{t^{2}}\right)}{3 / 8\left(\frac{9 a^{2}(1+v)}{t^{2}}\right)}=3 / 4 \cdot \frac{8}{z} \frac{(2)}{1+v}=\frac{2}{1.3}=1.54
$$

$\frac{7}{7}-\frac{53,500}{351100}=1.525 \approx 1.54$ suie sugin cheregres

and $\approx$ equast thes Tubesh if is a clampes celfe. 
ALCO PRODUCTS INC.

Bì DATE SUBJECT

CHKD. BY DATE

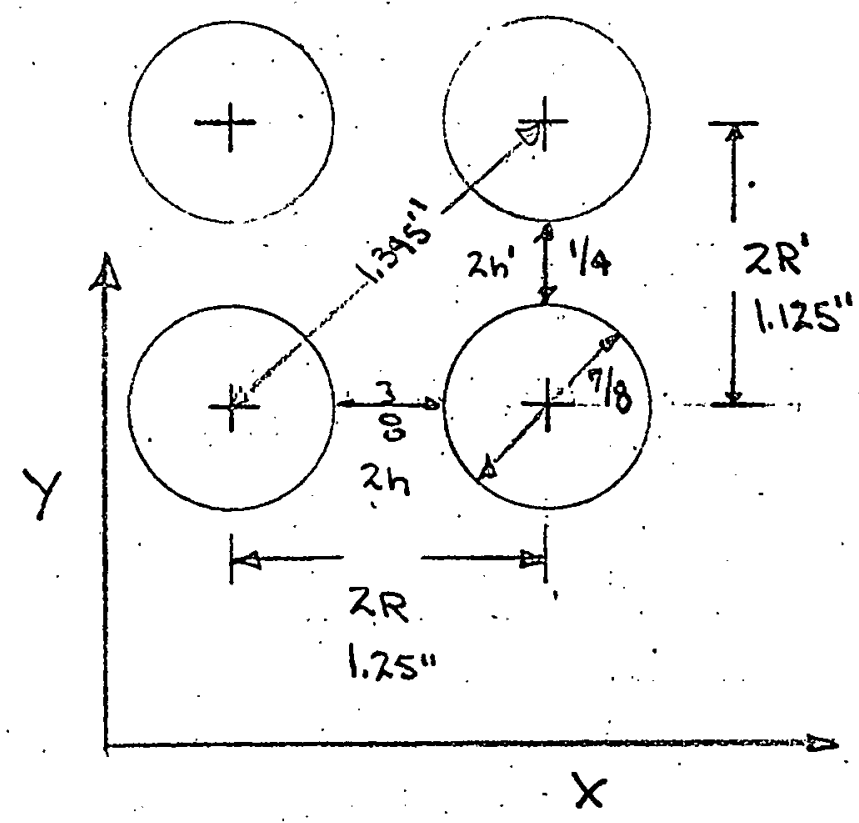

$x$ divection

$$
\begin{aligned}
& \sigma_{\text {edace }} \frac{6 M r}{h^{2}}=\frac{6(-53,500)}{(6.125)^{2}}=-8,560 \\
& 37.5 \\
& \sigma_{\text {ceuter }}=\frac{6(35,100)}{37.5}=5,620
\end{aligned}
$$

The Following Analysis is by ASME papa b1-wa-lls "Design of perforated plates" by W.J.Ol Dow Bell A) B. F. Langer

Alrkoug this pupan is for A trianquilar Pattan An Altampt is made to consider the $x \frac{1}{d} y$ duestions separatiely

$\therefore \quad \frac{F}{h}=\frac{\frac{10}{8}}{3 / \phi}=\frac{10}{3} \quad \& \frac{h}{R}=.3$

$\therefore$ Fig lo $K=1.04$; $\infty \beta=.31$

$$
=29,700
$$

$$
\begin{aligned}
\sigma_{\text {effox }} & =k \frac{E}{n}\left|\sigma_{\text {entur }}\right| \\
& =1.04,\left(\frac{10}{3}\right)|5,620|=19,450
\end{aligned}
$$

Ydirection

$$
\begin{aligned}
& \gamma_{\text {dffe }} y=1.04(4.5)|8,560|=40,100 \quad \& \frac{h^{\circ}}{k^{\circ}}=.222 \\
& \sigma_{46 y}=1.04(4.5)(5,620 \mid=26,300
\end{aligned}
$$

$$
\frac{R^{\prime}}{h^{\prime}}=9 / 8 \frac{8}{2}=9 / 2=4.5
$$




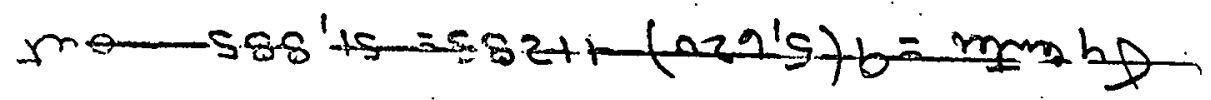

$$
\begin{aligned}
& 58 \varepsilon^{\prime} 8 L=5821+\mid 095816=23 p 2 \%
\end{aligned}
$$

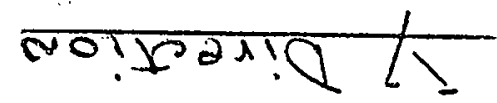

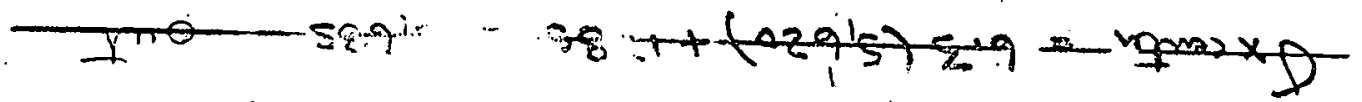

$$
\begin{aligned}
& \text { S81'S5 }=5.21+|0958| 59=2 \text { spax }
\end{aligned}
$$

$\rho: 11$

$$
b=h \quad \begin{aligned}
& 222 \cdot=2 / 4 \\
& \text { noingaip }
\end{aligned}
$$

$2 \cdot L$

b.

$$
\begin{aligned}
& \varepsilon^{\circ}=1 . \because \quad \varepsilon^{\prime}=4 / 4 \quad .5821+. \\
& \text { mongonip } x \\
& d+* D K=\tan D
\end{aligned}
$$

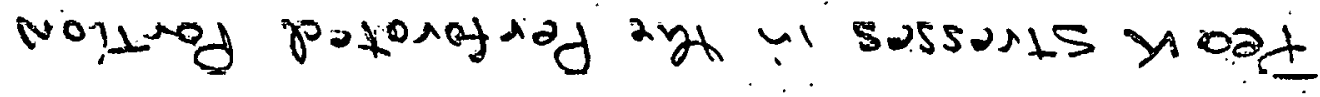

$$
|\Sigma=|-|\varepsilon|=z=1-\frac{S 251}{z}=-2 p
$$

$S+\frac{S_{1} 1}{2}=n+1$

$$
\frac{n+1}{2}=\frac{001^{\prime} 52}{005^{\prime} \operatorname{se}-}=5251
$$

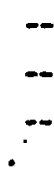


BY.

DATE

SUBJECT

SHEET NO... 7

CHKD. BY

DATE

JOB NO.

PEAK STRESSES IN PERFORATION ADj ACENT TO RIM

$$
\sigma_{\text {max }}=K_{r} \sigma_{\text {rim }}+P
$$

$e=$ radio

$b=$

$x$ direction $b / R=.3$

$K=2.3$

$$
\begin{aligned}
& \frac{f}{b}=\frac{7 / 16}{\frac{31}{16}}=7 / 16+10.226 \\
& \text { OT }=331 / 2 \\
& \therefore b=\frac{373 / 8-331 / 2}{2}=\frac{31}{16}
\end{aligned}
$$

$\sigma_{\max x}=2.3|8,560|: 12: 5=20,965$ (tow)

$\sigma_{\text {enter }}=2,3|5,620|-125=195$

THER MAL STrESS

$$
\begin{aligned}
\sigma_{\max } & =\operatorname{E\alpha T} \frac{\left(T_{p}-T_{s^{\prime}}\right)}{(1-\gamma)} \\
& =\frac{26.6 \times 10^{6} p \operatorname{ps}\left(51^{-0}-40^{3}\right)\left(T^{\prime} \times 10^{-6}\right)}{7^{-1}} \\
& =10.600
\end{aligned}
$$

dr Thermal Expansion

To= Primary temp $=510^{\circ} / 50^{\circ}$

$T s^{\prime}=$ Metal tour $\approx 463^{\circ}$

onsecowd Sun f.

$E\left(s, 0^{\circ}=26.6 \times 10^{6} \mathrm{psi}\right.$

$\alpha=7 \times 10^{-6}$

sis,

46:

$*$ 
ALCO PRODUCTS INC.

BY

SUBJECT

SHEET NO... 8 -...OF.

CHKD. BY DATE

SUBJECT

JOB NO.

STresses For Temperature drop Across. Diametral lane of $O$ Tube Type STeam Generator Tube sheet.

$$
\begin{aligned}
& \sigma_{\max }=\frac{K_{u} E^{x} \alpha_{T}\left(T_{H}-T_{C}\right)}{2}
\end{aligned}
$$

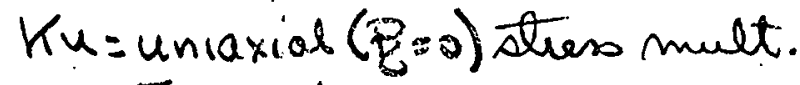

$$
\begin{aligned}
& \text { From Fisk } 12 \\
& k u_{x}=7.8 \propto h / k_{x}=3 \\
& k=y=11 \text { \& } h / R_{y}=.222 \\
& \text { From Fig } 5 \\
& =K u E * \frac{7 \times 10^{-6}(500-4,9)}{2} \\
& \frac{E^{x}}{E}=.25 \otimes h / R_{x}=.3 \\
& \frac{E^{*}}{E}=.16 @ h / R_{y}=.222 \\
& =K u E^{*}\left(283 \times 0^{-6}\right) \\
& T_{H}=500 \\
& t_{c}=419^{\circ} \\
& \gamma=7 \times 10^{-6} \\
& \text { W }\left\{\begin{array}{l}
\text { Decay } \\
\text { heat } \\
\text { Cold. }
\end{array}\right.
\end{aligned}
$$

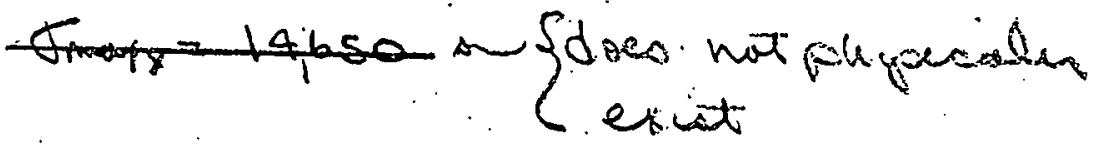

$\underline{y} \operatorname{direction}$

$$
\begin{aligned}
\sigma_{\text {max y }} & =11(.16)(26.6 \times 106)\left(233 \times 10^{\circ}\right) \\
& =13,250
\end{aligned}
$$


ALCU PRODUCTS INC.

BY

DATE

CHKD. BY

DATE
SUBJECT
SHEET NO. $G$

JOB NO

STress ot the edges of the holes adjacent to the un per forated diametral lane

$$
\sigma_{\text {max }}=\frac{K_{D} E \sigma_{r}\left(T_{H}-T_{C}\right)}{2(1-\gamma)}
$$

Only in advections

$$
\begin{aligned}
\sigma_{\max } & =\frac{1.62\left(26.6 \times 10^{6}\right)\left(7 \times 10^{-6}\right)(500-419)}{2(1-3)} \\
& =17,450
\end{aligned}
$$

$$
\begin{aligned}
& y . s=38,000 \quad \text { U It }=70,000 \\
& S A-350
\end{aligned}
$$

NAvy code

$$
\begin{aligned}
& S M=5 / 8 \times 38,000=25,300 \\
& 1.5 S M=35,600 \\
& 3 S M=71,100 \\
& y_{1} S_{1}=30,000 \\
& 50^{\circ}
\end{aligned}
$$$$
\begin{aligned}
& \text { From } F i q 14 \\
& K D=1.62
\end{aligned}
$$$$
\begin{aligned}
& \text { From } F i q 14 \\
& K D=1.62
\end{aligned}
$$$$
\frac{P}{D}=\frac{7 / 160}{40 / 16}=7 / 44=.159
$$ 
ALCO PRODUCTS INC.

BY

-DATE

CHKD. BY

DATE

SUBJECT

Hydro-CONDirions

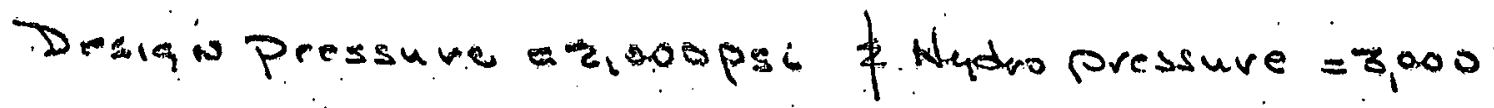

$\therefore$ From equation (10)

$$
\therefore \quad M d=\frac{q}{32(7.157)}\left[17.93 r_{0}^{2}-45.14 r^{2}\right]
$$

$\operatorname{Max} Q r=A$

$$
\therefore=\frac{3000}{32(7.157)}\left[-27.21(18.69)^{2}\right]=-124,500
$$$$
\sigma_{\text {doe }}=\frac{6 \text { Mr }}{h^{2}}=\frac{6(124,500)}{37.5}=-19,900
$$

Average stress

$$
\begin{aligned}
& \sigma_{y}=K_{x} \frac{R}{h}\left|\sigma_{\text {edge }}\right|=1.04\left(\frac{10}{3}\right)(19,900)=69,000 \\
& \sigma_{y}=K_{y}\left(\frac{R}{h}\right) \times\left|\sigma_{\text {edge }}\right|=1.04(4.5)(19,900)=9-3,200
\end{aligned}
$$

Peak stresses in the Perforated Portion

$$
\begin{aligned}
& \sigma_{\text {max }}=y \sigma_{*}+P \\
& \sigma_{x}=6.3(19,900)+3000=128,000 \\
& \sigma_{y}=9(19 ; 900)+3000=182,000
\end{aligned}
$$


ALCO PRODUCTS INC.

BY.

CHKD. BY _.....DATE
SUBJECT

[-1-
SHEET NO.J_l_._._OF.

JOB NO.

Peak STresses in Perforation Adjacent To Rim

$$
\begin{aligned}
\sigma_{\max }= & K_{r} \sigma_{\text {minim }}+P \\
& 2.3(19,900)+3,000=48,800
\end{aligned}
$$


ALCO PRODUCTS INC.

BY

DATE

CHKD. BY

DATE
SUBJECT

SHEET NO...12...OF.

JOB NO.

THERMAL STRESS dUE TO TEMPERATURE TrANSIENT

From Heat thausper Note

For. Face up flat Duffers wither free convection of water

$$
\begin{gathered}
h_{c=}=1.6 t_{f}{ }^{7}\left(\frac{\Delta t}{D}\right)^{.25} \\
h_{c=} 1.6(469)^{.7}\left(\frac{100(12}{18.69}\right)^{.25} \\
1.6(74)(2.83)=33 \frac{5.00 \mathrm{TH}}{\mathrm{Fr}^{2} \mathrm{hr}^{\circ} \mathrm{F}}
\end{gathered}
$$

From Page 61 Nauycode

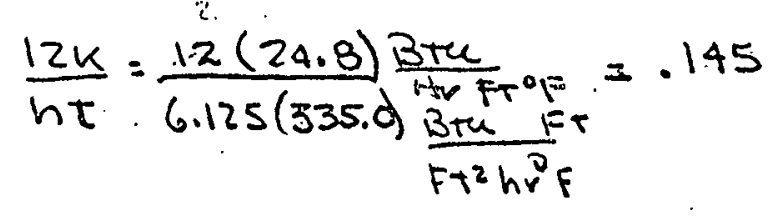

$\Delta t=100^{\circ}$ in $20: \therefore$.

$$
\frac{1}{4} \lambda=\frac{\sum \theta}{t^{2}}=\frac{0.018}{(6.125)^{2}} \frac{\mathrm{ln}^{2}}{\sec ^{2}} \times(20 \times 60) \sec =57 \dot{5}
$$

S18 time 20 min. 419

$t_{F}=\frac{518+419}{2} \approx 4690 . \quad \Delta T=518-468=50 \mathrm{~m} 5 \mathrm{~mm}$

$K=\frac{24.8 \text { Bree }}{\text { Hofrof N. Code }}$

$\notin \lambda=\frac{0.018(5 \times 60)}{37.6}=.144$

$\varepsilon=0.018 \frac{\mathrm{ln}^{2}}{x_{e}}$ No.code.

\& he $=1.6(493) .7\left(\frac{5 \times(12)}{18.69}\right)^{.25}=1.6(77)(2.38)=294$

Inst. Fd $=215$

$\frac{12 k}{h t}=\frac{12(24.9)}{6.125(294)}=.165$ 
ALCO PRODUCTS INC.

BY........ DATE

SUBJECT

SHEET NO.J3

CHKD BY

JOB NO.

Inside From Fig A.3-5 N.Code

Thermal shock

(1) (2) $\frac{12 k}{h_{t}}=.145+\lambda=.595 \quad \eta_{L}^{\prime}=.37=\frac{T_{m}-T_{i}}{\Delta T_{F}}$

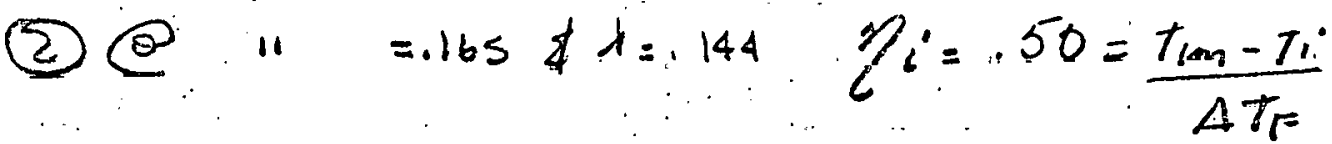

(1) $\sigma_{n}=\sigma_{r}=\frac{E \alpha(\Delta T F)}{1-\gamma} \eta_{i}=\frac{215(100) \cdot 37}{.7}=11,350 p^{2}$

(2) $\sigma_{h}=\sigma r=\frac{215(50)(.5)}{7}=7,680 \mathrm{psi}$

Outside

(e) $\frac{12 k}{n t}=0$ व $\lambda=.595 \quad \eta_{i}=.2$

(C) $"$

$\lambda=.144 \quad \eta_{i}=.245$

hot Applicable 
ALCO PRODUCTS INC.

BY.

CHKD. BY
SUBJECT

DATE
SHEET NO.. 14

JOB NO.

Startup at Shut down Cycle (Peak in ligaments)

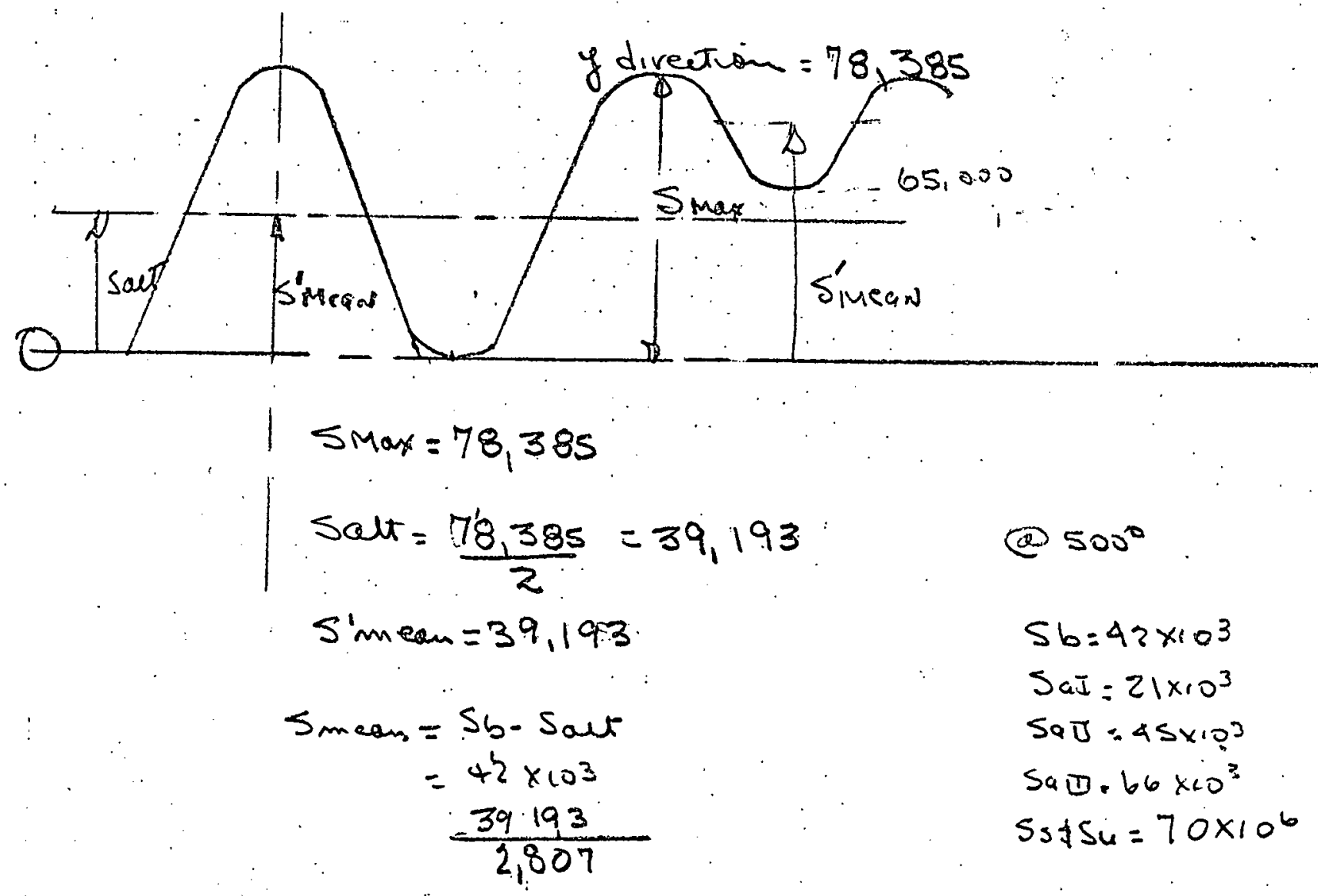

Hydro

$$
\begin{aligned}
& S_{\max }=182,000 \\
& \text { Sat }=91,000
\end{aligned}
$$

Full lond to lond

$$
\begin{aligned}
& S r=78,385-65000=13,385 \\
& \text { SalT }=6,694 \\
& \text { Símean }=71,691
\end{aligned}
$$

Simeon: Sb -Sat 
ALCO PRODUCTS INC.

BY

DATE

SUBJECT

SHEET NO.J_S

CHKO BY

JOB NO.

PM-2A operation a data (Normal operation)

$$
\text { Primáryside }\left\{\begin{array}{l}
1750 \text { psia-opereting } \\
518^{\circ} \mathrm{F} \text { - InleT To STeam Generator } \\
500^{\circ} \mathrm{F} \text { - OUTLT OF STeam Generator }
\end{array}\right.
$$

Secondary side $\left\{\begin{array}{l}465 \text { psia - } \\ 3060^{\circ} \text { INleT to Steam Generator } \\ 463^{\circ} \text { Outlet of STeam Generator }\end{array}\right.$

Coss of hoAd

Prumainside outlet $=$ to secondary side temp temp

$5000 \therefore P_{S}=680$ Poi 
ALCO PRODUCTS INC.

BY

DATE.

CHKD. BY.
SUBJECT.

loss of loAd
SHEET NO... I $6 . . . O F$.

JOB NO.

From Grminman paper it calculation she ct to 4

$$
\begin{aligned}
M \alpha & =q\left(4.36 \times 10^{-3}\right)\left[17.93 r_{0}^{2}-45.14 r^{2}\right] \\
Q r & =0 \quad \& \quad q=1750-680-1070 \\
& =29,200
\end{aligned}
$$$$
\text { @ } r=r_{0}
$$$$
M \alpha=-44,500
$$

$$
\begin{aligned}
& \sigma_{\text {edge }}=\frac{6 \cdot M_{r}}{h^{2}}=\frac{6(-44500)}{37.5}=7,130=\sigma_{1} \\
& \sigma_{\text {edge }}=\frac{6 M_{r}}{h^{2}}=\frac{6(29,200)}{37.5}=4,660
\end{aligned}
$$

As Per Sheet 4 usmc the 0 kinsey papa \& corf. beni the same (some Geometry)

$$
\begin{aligned}
& \sigma_{\text {eff }} x=k \frac{R}{n}\left|\sigma_{1}\right|=1.04\left(\frac{10}{3}\right)|7,130|=24,700 \\
& \sigma_{\text {eff } y}=k \frac{R}{n}\left|\sigma_{1}\right|=1.04(4.5)|7,130|=33,400 \\
& : B=1.31-1=.31 \quad \text { From sheet } 6
\end{aligned}
$$


ALCO PRODUCTS INC.

BY.

DATE.

SUBJECT

SHEET NO...

CHKD. BY_..... DATE

JOB NO.

Peak stresses in the Preforated Portion

$\sigma_{\max }=y \sigma_{4}+p$

xdivection $\sigma_{x}$ edge $=6.3(-45,130)+1070=46,070$

ydivection $\sigma_{\text {Hedge }}=9(7,130)+1070=65,000$

Peak stresses in Perforation Adjacent to Rim.

$$
\begin{aligned}
\sigma_{\max } & =k_{r} \sigma_{\text {rm in }}+P \\
& =2.3(7,130)+1070=17,470
\end{aligned}
$$

